\title{
OUTSOURCING AND STRATEGY IN SPANISH TOWN HALLS: A FIELD STUDY
}

MANAGEMENT DECISION. Vol. 51, N. 1, pp. 97-119. 2013.

\author{
Author Details \\ Author 1 Name: Reyes Gonzalez \\ Department: Business Organisation \\ University/Institution: University of Alicante \\ Town/City: Alicante \\ State (US only): \\ Country: Spain \\ Author 2 Name: Juan Llopis \\ Department: Business Organisation \\ University/Institution: University of Alicante \\ Town/City: Alicante \\ State (US only): \\ Country: Spain \\ Author 3 Name: Jose Gasco \\ Department: Business Organisation \\ University/Institution: University of Alicante \\ Town/City: Alicante \\ State (US only): \\ Country: Spain
}

\section{Corresponding author: Reyes Gonzalez \\ Corresponding Author's Email: mr.gonzalez@ua.es}

$\mathrm{X} \square$ Please check this box if you do not wish your email address to be published

\section{Acknowledgments (if applicable):}

This works was supported by the University of Alicante (Spain) - Vicerrectorado de Investigación, Desarrollo e Innovación- [GRE-09-08] and by Valencia Government -Consellería de Educación de la Generalitat Valenciana[GV72011/029].

\section{Biographical Details (if applicable):}

Reyes Gonzalez is a Senior Lecturer in Business Management and Information Systems at the University of Alicante. Her current research interests are Information Systems Management, E-Business, Outsourcing Processes and Public Administration Management. She has published articles in several journals, e.g. Business Process Management Journal, Information Processing and Management, Information and Management, Information Technology and People, International Journal of Information Management, Information Management \& Computer Security, Industrial Management \& Data Systems, Journal of European Industrial Training, Logistics Information Management, Total Quality Management, and The International Journal of Educational Management.

Juan Llopis is Dean of the Faculty of Economics and Professor of Business Organisation at the University of Alicante. Among his current research lines stand out Organisational Culture, Human Resources, Quality Management, Information Systems Management and Public Administration Management. He has published articles in journals like Information and Management, Total Quality Management, Journal of High Technology Management Research, Corporate Communications: An International Journal, Information Technology and People, Business Process Management Journal, Information Processing and Management, Journal of European Industrial Training, Logistics Information Management Journal, International Journal of Information Management, Information Management \& Computer Security, Industrial Management \& Data Systems and International Journal of Value-Based Management.

Jose Gasco is a Professor of Business Organisation at the University of Alicante. His current research interests include Human Resources, Information Systems Outsourcing and Public Administration Management. He has published articles in several journals, namely, Revue Internationale P.M.E., Direction et Gestion des Entreprises, Corporate Communications: an International Journal, The International Journal of Public Sector Management, Business Process Management Journal, Business Process Management Journal, Information Processing and Management, International Journal of Information Management, Information Management \& Computer Security, 
Industrial Management \& Data Systems, Total Quality Management, Journal of European Industrial Training, Information Technology and People, and Logistics Information Management.

\section{Structured Abstract:}

Purpose- In this study we are going to analyse the links between strategies, structures and processes in the case of the largest Spanish town halls, using the Miles \& Snow's models about organisational strategies, and asking ourselves the following questions: what is the situation of municipal services' outsourcing in the largest Spanish town halls?, do Spanish town halls follow the strategies suggested in Miles and Snow's model? and, is there a relationship between the strategic position adopted by town halls and their stance on outsourcing?

Design/Methodology/approach- In order to achieve these aims a questionnaire was administer to the Human Resource Managers in the town halls of the largest Spanish cities.

Findings- Outsourcing is a complement which seeks to improve the services delivered, and local institutions do not resort to it due to a lack of internal resources but as a way to complement their own capabilities.

Originality/value- The paper has identified three distinct strategic profiles in the town halls interviewed which coincide with the profiles that Miles \& Snow call prospective, defensive and reactive strategies. It is checked that town halls which outsource to a greater extent are the ones which identify more with the prospective or reactive strategy, whereas those which outsource less are closer to the defensive strategy.

Keywords: Outsourcing, Strategy, Spain, Town Halls

Article Classification: Research Paper

For internal production use only

Running Heads:

OUTSOURCING AND STRATEGY IN SPANISH TOWN HALLS: A FIELD STUDY

\section{INTRODUCTION}

Management in Public Administration has been involved in a new 'philosophy' or set of ideas known as New Public Management (NPM) since the late 1980s. NPM covers different themes (Hood, 1995), but is essentially focused on improving managerial efficiency in the public sector, copying ideas from private enterprises and orienting them towards an improvement in the service delivered to citizens (Jacobsen, 2005; Mathiasen, 1999; Yamamoto, 2003). NPM has been somehow seen as the new paradigm which must replace the bureaucratic administration that is typical of many public bodies and institutions (Gow 
and Dufour, 2000) and it needs new structures and management forms to achieve that goal. Among these new management modalities is the outsourcing of services.

In recent years, outsourcing has become a key strategy in the private sector when it comes to reduce the complexity of organisations, to control costs and, in short, to improve competitiveness. This strategy affects organisations' structures by determining that some activities which correspond to a firm can be carried out outside by a specialised provider, in return for an agreed price. Although there is a lot of research on outsourcing within the private sector, its study is not so common within the public sector and, more precisely, in municipal management. That is why we are going to ask ourselves the following question in this paper: what is the situation of municipal services' outsourcing in the largest Spanish town halls?

On the other hand, research on private organisations suggests that a good adjustment between strategies, structures and processes can be associated with better results; however, not much research has been done on this matter in the public sector (Andrews, Boyne, Law and Walker, 2009): more efforts are required to deepen into the links between strategy and other organisational features in this sector. This study has as its aim to analyse such links in the case of the largest Spanish town halls, for which we are going to use the paper written by Miles and Snow (1978) about models for organisational strategies. For this reason, we will ask ourselves a second and a third question: do Spanish town halls follow the strategies suggested in Miles and Snow's model? And, is there a relationship between the strategic position adopted by town halls and their stance on outsourcing?

We have structured this paper in a number of different sections to answer the aforesaid questions; after the introduction we will review the literature on public administrations, on strategy and public management, and will propose our study, taking into account the aspects in which it differs from the previous research works dedicated to outsourcing in public 
management. This will be followed by an explanation of the methodology applied during the fieldwork, where we justify the use of a questionnaire administered to Human Resource (HHRR) Managers in the town halls of the largest Spanish cities. The paper will finish with a summary of the main results and conclusions drawn from our research.

\section{CONCEPTUAL BACKGROUND}

\section{Outsourcing in Public Management}

The notion of NPM demands, on the one hand, the reduction and/or 'rightsizing' of the public sector, the adoption of market-based principles and the assumption of responsibilities and government programmes by the private sector (Bradbury and Waechter, 2009). Therefore, service outsourcing, which could be called also commissioning or contracting out (Willcocks and Currie, 1997), enters public administrations under NPM, which conceives it as a key tool to achieve economic efficiency (Helgason and Klareskov, 2005). However, not only economic considerations but also political ones promote outsourcing to a greater or lesser extent, this trend being clearly favoured by governments with a neoliberal slant (Young, 2007). Furthermore, different countries in the world have embraced outsourcing and other NPM recommendations more fervently than others. Thus, while Anglo-Saxon countries have witnessed the birth and have enthusiastically welcomed both NPM and outsourcing -it is the case of the United Kingdom, Australia or New Zealand- other countries have not been so proactive; it is the case of Continental Europe and, therefore, the case of Spain. What we need to make clear is that many of the public services are nothing special and can therefore be regarded as any other business (Helgason and Klareskov, 2005), as long as they fulfil the type of social and public objectives for which they were conceived. The following issues should be considered before a service outsourcing decision in public management: 
Priority of activities and outsourcing. According to Young (2007), those services which are not seen as basic (core services) are more prone to be outsourced; however, the most complex and professional areas are more difficult to outsource due to the power owned by workers and to the difficulty in measuring and controlling the specifications related to services. On the other hand, according to Helgason and Klareskov (2005), the outsourcing of uncomplicated, low-category services can only bring limited benefits, whereas complex services have a greater potential to generate cost savings if they are outsourced. The dilemma lies in the fact that the more complexity of tasks and the more potential savings, the more risk of failure in outsourcing. Before these unclear results drawn from previous research works, it seems advisable to try to determine the priority or importance of the different public services and analyse the link between that priority and the outsourcing level. Impact caused by outsourcing on service improvement. Outsourcing permits to improve services because access is gained to the knowledge and capabilities of providers supposedly specialized in such services (Cannadi and Dollery, 2005). Furthermore, services improve because organisations focus on key operations and outsource the least strategic ones (Brown and Potoski, 2003); this argument stems from the idea that any organisation must be able to identify its competitive advantages, focus on them and give up carrying out activities for which it is not specialised and in which it is not efficient. Another of the arguments on which this improvement is based has to do with the fact that outsourcing makes possible a transfer and flow of knowledge between providers and customers of the outsourced services (Norton and Blanco, 2009).

Outsourcing and control over the services delivered. The achievement of the abovementioned improvements will only be possible if governments and public administrations manage and supervise the outsourced services much more closely than when these services are delivered internally (Marvel and Marvel, 2007). Public managers need to 
have a number of competences and capabilities which allow them to assess the feasibility of the external service; they must equally have the power to implement projects and evaluate the services delivered (Bradbury and Waechter, 2009). Many outsourcing projects in public management have failed because they underestimated its real needs; time is required for provider management (Brown and Potoski, 2003). Public bodies can see outsourcing as a strategy to minimise the complexity of public management and somehow reduce or play down its responsibilities, being unaware of the fact that management needs to change its orientation, from managing and supervising civil servants to managing and supervising providers.

Influence exerted by outsourcing on cost control. Outsourcing makes it possible to control costs and achieve more efficiency. This is due to the fact that when one proceeds to outsource, the need arises to control the services delivered in a systematic way (Helgason and Klareskov, 2005), which is why those activities that are not outsourced are subjected to analysis seeking to determine how much it costs to deliver these services internally and comparing that cost with the price that an external provider would charge us. In this way, outsourcing makes us rethink how competitive we are with respect to the market.

Outsourcing additionally permits to obtain labour flexibility (Young, 2007). The customer of these services does not hire a worker but the services of a firm for a limited period of time, and it will be that firm's responsibility to deal with labour relations and the costs linked to them. However, many outsourcing contracts are long-term ones. This is an interesting paradox, since outsourcing theoretically turns fixed costs (for instance, those associated with workers on the staff of public administrations, or those related to the equipment and infrastructures needed to deliver public services) into variable costs (the monthly payment to the outsourcing provider). In any case, the truth is that outsourcing contracts in public 
management are mostly long-term contracts, which is why the long-sought flexibility in management could become a myth.

Influence exerted by outsourcing on the image of public management before the citizens. Since public organisations are perceived as inefficient and bureaucratic in most cases, promoting ideas related to outsourcing, especially during periods of elections or economic crises, in order to demonstrate their wish to make political changes in this area (Bensghir and Tekneci, 2008) is likely to be well received. Nevertheless, outsourcing may also have negative effects on the image of public administrations for the following reasons:

- The distance between government and citizens increases (Norton and Blanco, 2009).

Quite a few citizens are likely to perceive that, due to outsourcing, the State becomes increasingly separated from them because the private firm which delivers the outsourced services stands between these citizens and their government.

- Politicisation in service delivery: politicians have intervened too often in contracting with private providers, with quite a few cases of corruption and favouritism when it comes to award public contracts (Fernandez, 2007).

- The State becomes empty of its content: if public administrations ultimately try to outsource any public service, the risks exist for the State to lose all its content, its role being limited to encourage providers to compete for the delivery of public services (Norton and Blanco, 2009).

\section{Strategy in Public Management}

Strategic planning could still be regarded as something rather unusual in public administrations during the 1980s. Thus, Eadie (1983) highlighted that strategic planning in the public sector was still in its infancy and Denhardt (1985) pointed out that, although strategic planning was already essential for private firms and for some public bodies, it was 
not frequent at all in the context of local administrations. However, strategic approaches in the public sector, and more precisely in local administrations, stopped being an option to become a necessity by the mid-1990s, as is highlighted by Bolton and Leach (2002). This happened because both the financial restrictions and the requirements to improve efficiency made it necessary to use tools which could help these institutions to orient themselves within an environment that was, to say the least, uncertain. It can consequently be stated that strategic planning and management techniques have fully entered the public sector in the last twenty years (Poister and Streib, 2005). Both academicians and private sector executives have shown great interest during this period in trying to determine how the use of strategic management tools could improve business performance. This has also been the case in public management, local administrations being the area which has received the most attention in the literature.

Among the different strategic management models stands out that of Miles and Snow (1978), one of the most often used in the study of the public sector. Thus, Greenwood (1987), Poister and Streib (2005), Meier, O’Toole, Boyne and Walker (2007), Enticott and Walker (2008) and Andrews, Boyne, Law and Walker (2009) have published papers where that model provides the basis for the analysis of local administrations, public schools or other types of public bodies.

Miles and Snow's model (1987) defines a typology of organisational strategies which contains four ideal types: Prospectors, Defenders, Analysers and Reactors.

Prospectors: these are vanguard organisations which almost permanently seek opportunities in the market and which experiment on potential responses to its emergent trends. They are usually pioneers in new products and/or new customers.

Defenders: these are traditional organisations with a conservative vision of new product development. They typically compete in price and quality rather than with new products or 
markets, and especially dedicate their attention to improve efficiency in their existing operations.

Analysers: they represent an intermediate category between prospectors and defenders.

Reactors: these are organisations without a clearly defined strategy in which, despite perceiving high uncertainty levels, executives do not have a consistent strategy to react before that uncertainty. Reactors hardly ever make adjustments of any kind until they are forced to do so by pressures in the environment.

Many authors such as Conant, Mokwa and Varadatajan (1990) criticise the models which classify strategies in watertight typologies, as each organisation does not follow only one type of strategy; on the contrary, it is usual to find hybrid strategies. This is the case in public organisations because they have to satisfy a wide range of objectives which compete with one another and are observed by different types of parties involved (citizens, politicians, mass media, users, regulators, etc.) (Andrews, Boyne, Law and Walker, 2009). It is consequently better to assume that strategy categories are not watertight; instead, a continuum exists between the different categories. This would imply that the 'analysers' category is redundant, as it represents the combination of two categories (prospectors and defenders).

\section{Our proposal: Outsourcing and Strategy}

Table 1 collects some of the works which have analysed outsourcing in the public sector, specifying the goal sought in each one of them as well as their methodology; we add information about the aims and methodology of the present paper in the last row.

INSERT TABLE 1

\section{METHODOLOGY}


Based on the assumption that the largest town halls apply more strategic management techniques, such as outsourcing (Agranoff and McGuire, 2003; Berman, 1996; Boje and Whetten, 1981; Poister and Streib, 2005), we decided to send a questionnaire to the town halls of the largest Spanish cities, taking the number of inhabitants as the index for town hall size. For that purpose we have used the database called La Web Municipal ${ }^{1}$ [The municipal website]. Although looking for multiple information sources in each town hall would probably have been interesting in order to provide a more varied perspective in the results, we decided to administer the questionnaire only to the Human Resources managers because working with a single informant could allow us to obtain better response rates. Furthermore, HHRR managers have an overall vision of the organisations where they develop their professional activity as well as a wide knowledge of the organisational strategy (Kulik and Perry, 2008), which is why we thought that they are good candidates to answer the questionnaire.

The questionnaire was prepared taking as a reference the literature on strategy in town halls and was reviewed by three experts in local administration management. After uploading it to a web page, we sent a postal letter to the different town halls (c/o the Human Resources manager) letting them know that we would like them to complete the questionnaire the link for which was included in that letter. Next we made a follow-up via telephone which allowed us to access the e-mail address and/or telephone number of the HHRR manager or the Town Hall, and a second call was made via e-mail. A final telephone call was made in order to increase the response rate. Although the total questionnaire includes 17 items, only 5 of them are analysed in this paper.

We have examined 388 answers from 1,000 town halls interviewed, which represents a $38.8 \%$ response rate (sampling error: 3.8\%). Table 2 shows the study technical

\footnotetext{
${ }^{1}$ http://www.lawebmunicipal.com
} 
specifications. It is worth highlighting that the number of answers is superior or similar to that obtained in other research studies carried out in local administrations (Enticott and Walker, 2008; Proeller, 2007; Sebaa, Wallace and Cornelius, 2009). The town halls which answered the questionnaire are representative of the total population in terms of size (measured by number of inhabitants) and regarding territorial distribution, as all the Autonomous Regions are represented in the sample. Student's t-test $(\mathrm{t}$ value $=0.838$; significance $=0.402$ ) was used to determine the possible mean difference in the sample by size (number of inhabitants). The degree of independence between Autonomous Region and response level was determined by means of the Chi-square test (Chi-square value $=13.842$; significance $=0.610)$.

\section{INSERT TABLE 2}

Table 3 presents the measurements corresponding to the most important variables used in the study along with their reliability level. It is worth pointing out that the activities identified in each town hall reflects those which are usually performed in most of them, as the authors have detected through their consulting and research experience in local administrations.

INSERT TABLE 3

\section{RESULTS}

\section{Characteristics of Town Halls and Interviewees}

\section{INSERT TABLE 4}

Table 4 confirms that the town halls which answered the questionnaire have a large size, as it can be checked that the average number of inhabitants exceeds 40,000 and that we find ourselves before organisations with an average annual budget of more than 93 million euros and staff numbers of nearly 400 people on average. 
As for interviewees (Figure 1), since the questionnaire was addressed to the Human Resources manager in these local institutions, we can see that that a high response rate came from those jobs or positions $(42 \%)$, but we also find interviewees who identify themselves only as technicians (24\%) or HHRR administrative workers (11\%). The answer undoubtedly lies in the fact that this happens in smaller town halls where the tasks related to human resources are carried out by individuals who, despite their position and responsibilities, are not considered within the 'head' category. Moreover, the questionnaire was completed by politicians (mayor, deputy mayor or town hall secretary) in $8 \%$ of the cases.

We can see how the interviewees are mostly men, although without an excessive imbalance ( $56 \%$ of men as opposed to $44 \%$ of women) and how their age range is mostly situated between 40 and 49 years of age. On the other hand, a majority of interviewees is located in group A (78\%); this group is formed by employees whose job requires having completed university studies. A much smaller number belongs to group $\mathrm{C}$, administrative staff for whom university studies are not a requirement. Although $40 \%$ of the interviewees do not have a very high seniority, as they have occupied the position for 5 years, the average seniority in the job is 10 years. In our opinion, all these characteristics about the profile of interviewees allow us to state that they fulfil all the training, seniority, hierarchy and position requirements needed to make them apt to answer our questionnaire.

\section{INSERT FIGURE 1}

\section{Outsourcing}

\section{INSERT TABLE 5}

The importance or priority that each town hall assigns to its different services and the extent to which these services are outsourced appears in Table 5. The first outstanding aspect is the fact that the different town halls assign quite a lot of importance to all the areas mentioned, since all of them are assessed above the average. To this must be added that there is not a 
significant difference between the most valued areas and the least valued ones; in short, all services are generally seen as being very important.

Nevertheless, that same table equally reflects a low outsourcing level in the last columns, as even the most often outsourced service, namely cleaning, parks and rubbish collection, receives an average subcontracting score of 4.96 , just above the average value on the likert scale, which is 4 . Moreover, the rest of services are outsourced to an even lesser extent. A special mention must be made of the public safety area which is carried out -as it could logically be expected- by staff belonging to the town hall itself, since this task falls upon civil servants by law in most cases.

Next we tried to check the possible existence of a positive or negative relationship between the importance given by town halls to the different services and the extent to which those services are outsourced. For this purpose, we have carried out a correlation analysis and later reinforced our conclusions with a mean difference test. We have elaborated a new variable called 'outsourcing degree, ${ }^{2}$ in order to perform that analysis. This variable discriminates whether a town hall outsources above or below the average. Its calculation results from adding up the scores (from 1 to 7 ) given to the extent to which each service is outsourced by each town hall, which in turn gives rise to a new variable known as 'outsourcing sum.' We have calculated the mean and median of that sum (45.6 and 45.5, respectively). Then, the 'outsourcing degree' arises from giving a value 1 (it outsources above the average) to those town halls with a total outsourcing sum exceeding 45.5 , while a value 0 (it outsources below the average) is given to those with a sum of less than 45.5. The median allows us to have a

\begin{tabular}{lcr}
\hline 2 & & \\
\hline Outsourcing degree & No. & \multicolumn{1}{c}{$\%$} \\
\hline Below Average & 194 & 50.0 \\
Above Average & 194 & 50.0 \\
Total & 388 & 100.0 \\
\hline
\end{tabular}


central cut-off measure with 194 town halls which outsource below the average and another 194 which outsource above the average.

\section{INSERT TABLE 6}

Many positive correlations -significant in a lot of cases- between the importance assigned to the different services delivered by a town hall and their outsourcing level can be observed in Table 6. Furthermore, Student's t-test or the non-parametric Mann-Whitney U-test, used when there is no homoscedasticity in the variables, enables us to reinforce this conclusion once more, that is, the more priority or importance is given by the town hall to a particular activity, the more often services related to that activity are outsourced. The only activity which has a completely opposite sign compared to the rest is public safety -already mentioned above- where the correlation between the importance given to this area by the different town halls and the extent to which it is outsourced turns out to be negative (though non-significant).

\section{INSERT TABLE 7}

We can additionally check (Table 7) that a relationship exists between the size of a town hall (measured by number of inhabitants in the municipality, its budget and its staff volume) and the proclivity to outsource activities. The town halls which outsource the most are also those with a greater size, more inhabitants, a larger budget and more staff. The non-parametric Man-Whitney U-test has made it possible for us to verify this relationship.

Regarding the opinion of town halls about outsourcing (Table 8), they underline that it contributes to a better service for citizens and that outsourced services are properly controlled by town halls. It is also seen as relevant, though to a lesser extent, that outsourcing permits to reduce costs. On the whole, town halls do not seem to think that they have a large number of services subcontracted with other firms. Neither do they think that increasing the outsourcing level would permit to improve services even more. In general, we 
detect a rather conservative stance in relation to outsourcing among the town halls interviewed; it can actually be seen by the mean, the median and the mode for the items consulted that their views about outsourcing are not excessively enthusiastic in most cases.

\section{INSERT TABLE 8}

\section{Strategy}

\section{INSERT TABLE 9}

Regarding the strategic profile of town halls (Table 9), we can identify as one of its most relevant features the interest in achieving qualitative aims and ensuring that their services reach the highest possible number of users, without this meaning that diversity and respect for the needs of social minorities are disregarded. Furthermore, town halls seek novelty in the services that they offer, trying at the same time not to neglect the traditional areas. As for their attitude towards outsourcing, the results in Table 6 are confirmed, since town halls mostly seek the use of their internal resources rather than the involvement of the private sector in the delivery of their services. Town halls often admit that they do not have a good short-term or long-term planning and that they are not very innovative or advanced either.

A Principal Components factor analysis with the information about the items related to the strategic stance of town halls comes next. This factor analysis seeks to reduce the information offered by the original variables into a set of factors or constructs which underlie that information, and with a fewer number of variables than in the original group. Each factor can thus be considered a combination of several original variables. Highlighting the underlying factors in each group has as its aim to obviate the redundant or less important information. We have checked that this type of factor analysis is pertinent ${ }^{3}$. Kaiser's

3

\begin{tabular}{|l|r|}
\hline Correlation Matrix Determinant & 0.024 \\
Kaiser-Meyer-Olkin Index & 0.828 \\
Bartlett Test of Specificity & 1293.441 \\
Significance & 0.000 \\
\hline
\end{tabular}


criterion suggests that it would be advisable to extract three factors, as there are three eigenvalues above 1 which account for $60.646 \%$ of the information provided by the original variables (a satisfactory ratio because it exceeds 50\%). We have carried out a Varimax rotation because it allows a better interpretation of factors; the results drawn from this analysis can be found in Table 10 .

INSERT TABLE 10

The first factor basically coincides with the features that characterise the Prospective strategy; this is why we call it prospective strategy. The town halls which adopt this strategy seek to offer more innovative, vanguard services; moreover, they try to diversify their services as well as their markets (new services for existing users and existing services for new users); they equally pursue a strategy which caters both for a large number of users and for minorities, and these are also the town halls which develop both their short-term and their long-term strategy most carefully.

The second factor is associated with the defensive strategy, which essentially seeks to continue offering the traditional services and to obtain a good output from its internal resources. The item referred to cost reduction contributes with nearly the same degree of participation both in this factor and in the previous one, which is why we have decided not to interpret it because we cannot correlate it with any separate factor.

Finally, the third factor is clearly connected with the reactive strategy, the one which is common in organisations which only act driven by external pressures and which, in this case, more decidedly seeks the involvement of the private sector in the delivery of typical town hall services.

\section{Outsourcing and Strategy}

The next step is to find out which town halls assign higher value to the different services that they deliver. This will allow us to check if there is a link between level of importance and 
strategic profile. Later on, an attempt will be made to determine the possible relationship between strategic profile and outsourcing degree. The analysis that we have carried out here is identical to the one reflected in Table 6 , with the profile of each town hall and the importance that it assigns to each activity. We have built the 'importance of the activity' variable in more or less the same way as the 'outsourcing degree' variable. Similarly, a new variable has been calculated for each one of the town hall activities depending on whether that activity was more or less important for a given town hall, that is, on whether it had a level of importance above the average or below the average. In this case, we also take the median for each activity's level of importance as the central or cut-off measure (see Appendix I) ${ }^{4}$. The prospective strategy correlates positively with the importance given to all town hall functions. Mean difference is significant too, that is, those town halls which consider each function more important identify more clearly with the prospective strategy. Also the town halls which adopt the defensive strategy assign great relevance to most town hall activities (except for the case of activities related to public transport and old town revitalisation). Instead, town halls which are closer to a reactive strategy are the ones which give the least importance to many town hall functions.

\section{INSERT TABLE 11}

We can verify in Table 11 how town halls which are closer to proactive and reactive stances outsource more than those which are further from these stances. However, town halls which are closer to the defensive strategy outsource below the average. In this last case, the level of significance between both variables (defensive strategy and outsourcing degree) is lower than in the previous cases $(90.8 \%)$, but even so it is still possible to see the mean difference between both variables.

\footnotetext{
${ }^{4}$ The corresponding tables, which are similar to Table 6 , are included in an appendix to make reading easier.
} 


\section{CONCLUSIONS}

The survey carried out among the largest Spanish town halls reveals the low level of outsourcing in municipal services, the cleaning, parks and rubbish collection service being the most often outsourced, and the public safety service the one in which the participation of external firms is least sought. Even in the most often outsourced activities, there is only partial trust in the collaboration of external services; in other words, town halls opt for a partial or selective type of outsourcing, rejecting the practice of total or extreme outsourcing (Bradbury and Waechter, 2009). We can additionally observe the existence of a positive relationship between the importance that each town hall assigns to the different activities and the outsourcing degree, that is, the more importance is given to an activity, the more they resort to collaboration with external firms (except in the case of the aforementioned public safety activity). On the other hand, larger-sized town halls (with a greater number of inhabitants, a higher budget and a greater staff volume) are the ones which most often hire external firm services. This leads us to think that outsourcing in Spanish town halls is a complement which seeks to improve the services delivered, and that these local institutions do not resort to it due to a lack of internal resources but as a way to complement their own capabilities. The opinions expressed by town halls, according to which outsourcing can help to deliver a better service to citizens and is not a strategy which serves above all to control costs, are in keeping with the results obtained in previous studies (Norton and Blanco, 2009). In any case, it can be said that the attitude of town halls towards outsourcing is quite conservative in general terms. This conservative stance probably responds to the cultural models which are typical of Spain and even of Continental Europe as a whole (Helgason and Klarescov, 2005).

Regarding the strategic profile of town halls, we can identify as one of its most relevant features the interest in achieving qualitative aims and ensuring that their services reach the 
highest possible number of users, without this meaning that diversity and respect for the needs of social minorities are disregarded. Furthermore, town halls seek novelty in the services that they offer, trying at the same time not to neglect the traditional areas. As for their attitude towards outsourcing, it is confirmed that town halls seek above all the use of their internal resources rather than the involvement of the private sector in the delivery of their services. Town halls generally admit that they do not have a good short-term or longterm planning and that they are not very innovative or advanced either.

The utilization of a factor analysis has enabled us to identify three distinct strategic profiles in the town halls interviewed -the same as in the study of Andrews, Boyne, Law and Walker (2009) - which coincide with the profiles that Miles and Snow (1978) call prospective, defensive and reactive strategies, the first two being the strategies which generally assign more importance to the different town hall services, while the third one considers them less important. When we relate these strategic profiles to the attitudes of town halls before outsourcing, it is checked that town halls which outsource to a greater extent are the ones which identify more with the prospective or reactive strategy, whereas those which outsource less are closer to the defensive strategy. The explanation probably lies in the fact that the defensive strategy is more conservative and, therefore, perhaps takes outsourcing less into account as an option to offer or improve town hall services. Maybe reactive town halls resort to outsourcing because, since they do not give so much relevance to services, their aim is basically to reduce their responsibilities in that area. Instead, prospective town halls regard services as something very important and, as we said before, for them outsourcing represents a way to complement and improve their services.

As regards limitations, in methodological terms, our study is exclusively based on the analysis of the answers given by the Human Resources managers in the town halls interviewed. Despite the qualification that this position provides to express opinions about 
outsourcing, having access to the views of managers responsible for other local government areas would widen the vision about this topic. Furthermore, it would be interesting to contrast our conclusions with case studies where the people in charge of outsourced services could endorse -or challenge- those conclusions.

Regarding future lines of research, in our opinion, although some research studies have been devoted to outsourcing in the public sector, a lot of aspects still need to be examined. In the present analysis, we have focused on the interconnections between organisational strategy and outsourcing in the public sector, an issue that we had not seen being developed so far. In any case, the literature on outsourcing in the public sector still has to provide some clear guidelines that can help to know which services are important candidates to outsourcing and how the contracting of services must be effectively guided (Young, 2007).

\section{REFERENCES}

Agranoff, R. and McGuire, M. (2003). Collaborative public management: New strategies for local governments. Georgetown University Press. Washington D.C.

Andrews, R.; Boyne, G.A. and Walker, R.M. (2006). "Strategy content and organizational performance: An empirical analysis”, Public Administration Review, 66(1), pp. 52-63.

Andrews, R.; Boyne, G.A.; Law, J. and Walker, R.M. (2009). "Strategy, structure and process in the public sector: a test of the Miles and Snow Model”, Public Administration, 87(4), pp. 732-749.

Bensghir, T.K. and Tekneci, A. (2008). "An Evaluation of the Outsourcing IS/ICT Activities in Turkish Ministerial Computer Departments", Public Administration and Development, 28(2), pp. 94104.

Berman, E.M. (1996). "Local government and community-based strategies: Evidence from a national survey of a social problem", The American Review of Public Administration, 26(1), pp. 71-91. 
Boje, D.M. and Whetten, D.A. (1981). "Effects of organizational strategies and contextual constraints on centrality and attributions of influence in interorganizational networks", Administrative Science Quarterly, 26(3), pp. 378-395.

Bolton, N. and Leach, S. (2002). "Strategic planning in local government: A study of organisational impact and effectiveness", Local Government Studies, 28(4), pp. 1-21.

Boyne, G.A. and Walker, R.M. (2004). "Strategy content and public service organizations”, Journal of Public Administration Research and Theory, 14(2), pp. 231-252.

Bradbury, M.D. and Waechter, G.D. (2009). "Extreme Outsourcing in Local Government. At the top and all but the top", Review of Public Personnel Administration, 29(3), pp. 230-248.

Brown, T.L. and Potoski, M. (2003). "Contract-Management Capacity in Municipal and County Governments”, Public Administration Review, 63(2), pp. 153-164.

Cannadi, J. and Dollery, B. (2005). "An Evaluation of Private Sector Provision of Public Infrastructure in Australian Local Government”, Australian Journal of Public Administration, 64(3), pp. 112-118.

Claver, E.; González, R.; Gascó, J.L. and Llopis, J. (2002). "Information systems outsourcing: reasons, reservations and success factors", Logistics Information Management, 15(4), pp. 294-308.

Conant, J.S.; Mokwa, M.P. and Varadatajan, P.R. (1990). "Strategic Types, Distinctive Marketing Competencies and Organizational Performance: A Multiple Measures Based Study”, Strategic Management Journal, 11(5), pp. 365-383.

Denhardt, R.B. (1985). "Strategic Planning in State and Local Government", State and Local Government Review, 17(1), pp. 174-179.

Eadie, D.C. (1983). "Putting a Powerful tool to practical use: the Application of Strategic Planning in the Public Sector", Public Administration Review, 43(5), pp. 447-452. 
Enticott, G. and Walker, R.M. (2008). "Sustainability, Performance and Organizational Strategy: an Empirical Analysis of Public Organizations”, Business Strategy and the Environment, 17(2), pp. 7992.

Feiock, R.C. and Jang, H. S. (2009). "Nonprofits as Local Government Service Contractors", Public Administration Review, 69(4), pp. 668-680.

Fernandez, (2007). "What Works best when contracting for services? An Analysis of contracting Performance at the Local Level in The US", Public Administration, 85(4), pp. 1119-1141.

Gow, J.I. and Dufour, C. (2000): "Is the New Public Management a paradigm?", International Review of Administrative Sciences, 66(4), pp. 573-597.

Greenwood, R. (1987): "Managerial strategies in local government”, Public Administration, 65(3), pp. 295-312.

Helgason, K.S. and Klareskov, V. (2005). "When the Halo Wears Off”, Public Manager, 34(4). pp. $42-48$.

Hood, C. (1995): “Contemporary management”, Public Policy and Administration, 10(2), pp. 104117.

Jacobsen, D.I. (2005): “Sand in the machinery? Comparing bureaucrats' and politicians' attitudes towards public sector reform”, European Journal of Political Research, 44(6), pp. 767-799.

Kulik, C.T. and Perry, E.L. (2008). "When less is more: The effect of devolution on HR's strategic role and construed image", Human Resource Management, 47(3), pp. 541-558.

Lambright, K. T. (2009). “Agency Theory and Beyond: Contracted Providers' Motivations to Properly Use Service Monitoring Tools", Journal of Public Administration Research and Theory, 19(2), pp. 207-227.

Marvel, M.K. and Marvel, H.P. (2007). "Outsourcing Oversight: A comparison of Monitoring for InHouse and Contracted Services", Public Administration Review, 67(3), pp. 521-530. 
Mathiasen, D.G. (1999): “The New Public Management and its critics", International Public Management Journal, 2(1), pp. 90-111.

Meier, K.J.; O’Toole Jr., L-J.; Boyne, G.A. and Walker, R.M. (2007). "Strategic Management and the Performance of Public Organizations: Testing Venerable Ideas against Recent Theories", Journal of Public Administration Research and Theory, 17(3), pp. 357-377

Miles, R.E. and Snow, C.C. (1978). Organizational Strategy, Structure and Processes. McGraw-Hill. New York.

Murray, J. G.; Rentell, P.G. y Geere, D. (2008). "Procurement as a Shared service in English Local Government”, International Journal of Public Sector Management, 21(5), pp. 540-555.

Norton, S.D. and Blanco, L. (2009). "Public-private partnerships: a comparative study of new public management and stakeholder participation in the UK and Spain”, International Journal of Public Policy, 4(3/4), pp. 214-231.

Poister, T.H. and Streib, G. (2005). "Elements of Strategic Planning and Management in Municipal Government: Status after two Decades”, Public Administration Review, 65(1), pp. 45-56.

Proeller, I. (2007). "Outcome-orientation in performance contracts: empirical evidence from Swiss Local Governments", International Review of Administrative Sciences, 73(1), pp. 95-111.

Sebaa, A.A.; Wallace, J. and Cornelius, N. (2009): "Managerial characteristics, strategy and performance in local government”, Measuring Business Excellence, 13(4), pp. 12-21.

Ward, R.C. (2007). "The Outsourcing of Public Library Management. An Analysis of the Application of New Public Management Theories from the Principal-Agent Perspective", Administration \& Society, 38(6), pp. 627-648.

Willcocks, L.P. and Currie, W.L. (1997). “Contracting Out Information Technology in Public Sector Contexts: Research and Critique", Journal of Management \& Organization, 3(2), pp. 34-52.

Yamamoto, H. (2003). “New Public Management. Japan's practice”, Institute for International Policy Studies, Paper 293E. Download Sept/4/2009. 
Young, S. (2007). "Outsourcing: uncovering the complexity of the decision", International Public Management Journal, 10(3), pp. 307-325.

Young, S. (2008). "Outsourcing in Public Health: a Case Study of Contract Failure and its Aftermath", Journal of Health, Organization and Management, 22(5), pp. 446-464.

APPENDIX I: Strategy and Priority

INSERT TABLES 12, 13 and 14 
Table 1: Outsourcing Studies in the public sector

\begin{tabular}{|c|c|c|}
\hline Study & Objective & Methodology \\
\hline $\begin{array}{l}\text { Claver, González, } \\
\text { Gascó and Llopis } \\
(2002)\end{array}$ & $\begin{array}{l}\text { To study Information Systems outsourcing } \\
\text { reasons, risk and success factors in Spanish } \\
\text { public universities }\end{array}$ & $\begin{array}{lr}\text { A survey } & \text { among } 35 \\
\text { Information } & \text { Systems } \\
\text { managers in Spanish public } \\
\text { universities }\end{array}$ \\
\hline $\begin{array}{l}\text { Marvel and } \\
\text { Marvel (2007) }\end{array}$ & $\begin{array}{l}\text { To study the mechanisms used by town halls } \\
\text { to control outsourced activities, drawing a } \\
\text { comparison between these activities and the } \\
\text { ones which are internally managed }\end{array}$ & $\begin{array}{l}\text { A survey among } 137 \text { city } \\
\text { town halls at the USA }\end{array}$ \\
\hline Ward (2007) & $\begin{array}{l}\text { To study the outsourcing of services at public } \\
\text { libraries, specifically control mechanisms, } \\
\text { cost savings and citizen satisfaction }\end{array}$ & 7 case studies in the USA \\
\hline $\begin{array}{l}\text { Young } \quad(2007- \\
2008)\end{array}$ & $\begin{array}{l}\text { To study the outsourcing of public health } \\
\text { services, the reasons to outsource and the } \\
\text { characteristics of the outsourced services that } \\
\text { achieve good results }\end{array}$ & 4 case studies in Australia \\
\hline $\begin{array}{l}\text { Bradbury and } \\
\text { Waechter (2009) }\end{array}$ & $\begin{array}{l}\text { To study Extreme Outsourcing at local } \\
\text { administrations. We identify 'extreme } \\
\text { outsourcing' with two strategies: to outsource } \\
\text { everything except management or to } \\
\text { outsourcing nothing but management. }\end{array}$ & $\begin{array}{l}\text { Case Studies in the USA } \\
\text { (non-specified number) }\end{array}$ \\
\hline $\begin{array}{l}\text { Feiock and Jang } \\
(2009)\end{array}$ & $\begin{array}{l}\text { To study the involvement of non-profit } \\
\text { organisations in local services addressed to } \\
\text { seniors }\end{array}$ & $\begin{array}{l}\text { Survey. } \\
\text { information from a database. } \\
472 \quad \text { questionnaires } \\
\text { administered to town halls. } \\
\text { USA }\end{array}$ \\
\hline $\begin{array}{l}\text { Bensghir and } \\
\text { Tekneci (2008) }\end{array}$ & $\begin{array}{l}\text { To study Information Systems outsourcing at } \\
\text { Computer departments in Turkish ministries }\end{array}$ & $\begin{array}{l}\text { Survey. Turkey. } \\
\text { number of answers is not } \\
\text { specified }\end{array}$ \\
\hline Lambright (2009) & $\begin{array}{l}\text { To study suppliers' reasons to properly use } \\
\text { the tools required to control their services }\end{array}$ & 7 case studies in the USA \\
\hline $\begin{array}{l}\text { Murray, Rentell } \\
\text { and Geere (2008) }\end{array}$ & $\begin{array}{l}\text { To analyse the outsourcing of services at little } \\
\text { town halls through the establishment of } \\
\text { consortia }\end{array}$ & 6 case studies in the UK \\
\hline Our study & $\begin{array}{l}\text { To analyse the situation of outsourcing and } \\
\text { the relationship between outsourcing and } \\
\text { strategic positioning in the largest Spanish } \\
\text { town halls }\end{array}$ & $\begin{array}{l}\text { A survey among } 388 \text { large } \\
\text { town halls in Spain }\end{array}$ \\
\hline
\end{tabular}

Table 2: Study technical specifications

\begin{tabular}{ll}
\hline Scope & Spain \\
Population & 1,000 largest Town Halls (by population) \\
Sample size & $388(38.8 \%)$ \\
Sampling Error & $3.8 \%$ \\
Survey Date & July 2009-March 2010 \\
\hline
\end{tabular}


Table 3: Measures of variables and reliability

\begin{tabular}{|l|l|l|r|}
\hline \multicolumn{1}{|c|}{ Constructor } & \multicolumn{1}{|c|}{ Source } & \multicolumn{1}{c|}{ Measure } & $\begin{array}{c}\text { Reliability } \\
\text { (Cronbach's } \alpha \text { ) }\end{array}$ \\
\hline $\begin{array}{l}\text { Importance assigned to } \\
\text { town hall activities }\end{array}$ & Own materials & $\begin{array}{c}15 \text { items, 1-7 } \\
\text { likert scale }\end{array}$ & 0.934 \\
\hline $\begin{array}{l}\text { Outsourcing of town hall } \\
\text { activities }\end{array}$ & Own materials & $\begin{array}{c}15 \text { items, 1-7 } \\
\text { likert scale }\end{array}$ & 0.909 \\
\hline Opinion about outsourcing & $\begin{array}{l}\text { Brown and Potoski (2003); Murria, } \\
\text { Rentell and Geere (2008) and own } \\
\text { materials }\end{array}$ & $\begin{array}{l}6 \text { items, 1-7 } \\
\text { likert scale }\end{array}$ & 0.857 \\
\hline Town hall strategic profile & $\begin{array}{l}\text { Andrews, Boyne and Walker (2006); } \\
\text { Boyne and Walker (2004) and own } \\
\text { materials }\end{array}$ & $\begin{array}{l}11 \text { items, } 1-7 \\
\text { likert scale }\end{array}$ & 0.762 \\
\hline
\end{tabular}

Table 4: Town hall size

\begin{tabular}{lrrrrr}
\hline & \multicolumn{1}{c}{ Mean } & \multicolumn{1}{c}{ Median } & Mode & Maximum & Minimum \\
\hline No. of inhabitants & 41,579 & 16,102 & 6,434 & 566,447 & 6,434 \\
Budget $(€)$ & $93,082,000$ & $15,500,000$ & $7,000,000$ & $900,000,000$ & $5,200,000$ \\
Staff volume (No. of workers) & 381 & 190 & 200 & 5300 & 13 \\
\hline
\end{tabular}

Table 5: Town hall services, priority and outsourcing

\begin{tabular}{|l|c|c|c|c|c|c|c|}
\hline & \multicolumn{2}{|c|}{$\begin{array}{l}\text { Priority assigned by the } \\
\text { town hall to the service }\end{array}$} & \multicolumn{3}{c|}{ Outsourcing degree at the } \\
Town hall services & Mean & Median & Mode & Mean & Median & Mode \\
\hline Cleaning, Parks and rubbish collection & 5.54 & 6 & 6 & 4.96 & 6 & 7 \\
\hline Culture & 5.36 & 5 & 5 & 3.09 & 3 & 5 \\
\hline Public safety & 5.32 & 5 & 6 & 1.70 & 1 & 1 \\
\hline Sports & 5.31 & 5 & 6 & 3.38 & 4 & 4 \\
\hline Commerce, development and employment & 5.27 & 5 & 6 & 2.67 & 3 & 1 \\
\hline Town-planning and housing & 5.22 & 5 & 5 & 2.60 & 2 & 2 \\
\hline Seniors' programmes & 5.16 & 5 & 6 & 2.89 & 3 & 2 \\
\hline Underprivileged groups & 5.09 & 5 & 6 & 2.75 & 2.5 & 2 \\
\hline Youth programmes & 4.91 & 5 & 5 & 2.79 & 3 & 2 \\
\hline Tourism and promotion & 4.80 & 5 & 5 & 2.84 & 3 & 1 \\
\hline Environmental quality & 4.74 & 5 & 5 & 3.35 & 4 & 5 \\
\hline Facility maintenance & 4.68 & 5 & 5 & 3.90 & 4 & 5 \\
\hline Old town revitalisation & 4.49 & 5 & 5 & 2.77 & 2 & 0 \\
\hline Health & 4.11 & 4 & 4 & 2.47 & 2 & 0 \\
\hline Public transport & 4.10 & 4 & 4 & 3.41 & 3 & 0 \\
\hline
\end{tabular}


Table 6: Correlation analysis and equality of means test (priority and outsourcing)

\begin{tabular}{|c|c|c|c|c|c|c|c|c|}
\hline & & & & & Levene & & & \\
\hline Priority & Pearson's R & Sign. & Outsourcing Degree & Mean & $\mathrm{F}$ & Sign. & $\begin{array}{l}\text { T (student) or U } \\
\text { Mann-Whitney }\end{array}$ & Sign. \\
\hline $\begin{array}{l}\text { Cleaning, parks and rubbish } \\
\text { collection }\end{array}$ & 0.116 & $0.024 *$ & $\begin{array}{l}\text { Above average } \\
\text { Below average }\end{array}$ & $\begin{array}{l}5.095 \\
4.863\end{array}$ & 0.106 & 0.744 & 1.031 & 0.303 \\
\hline Facility maintenance & 0.139 & $0.007 *$ & $\begin{array}{l}\text { Above average } \\
\text { Below average }\end{array}$ & $\begin{array}{l}4.161 \\
3.666\end{array}$ & 4.753 & 0.030 & 2.404 & $0.017 *$ \\
\hline Public transport & 0.342 & $0.000 *$ & $\begin{array}{l}\text { Above average } \\
\text { Below average }\end{array}$ & $\begin{array}{l}4.182 \\
2.316\end{array}$ & 2.152 & 0.143 & 6.981 & $0.000 *$ \\
\hline Sports & 0.132 & $0.010^{*}$ & $\begin{array}{l}\text { Above average } \\
\text { Below average }\end{array}$ & $\begin{array}{l}3.618 \\
2.777\end{array}$ & 2.311 & 0.129 & 3.503 & $0.001 *$ \\
\hline Environmental quality & 0.028 & 0.593 & $\begin{array}{l}\text { Above average } \\
\text { Below average }\end{array}$ & $\begin{array}{l}3.437 \\
3.346\end{array}$ & 0.475 & 0.491 & 0.431 & 0.666 \\
\hline Culture & 0.090 & 0.080 & $\begin{array}{l}\text { Above average } \\
\text { Below average }\end{array}$ & $\begin{array}{l}3.185 \\
2.945\end{array}$ & 0.772 & 0.380 & 0.946 & 0.345 \\
\hline Seniors' programmes & 0.249 & $0.000 *$ & $\begin{array}{l}\text { Above average } \\
\text { Below average }\end{array}$ & $\begin{array}{l}3.181 \\
2.327\end{array}$ & 7.281 & 0.007 & 11330 & $0.000 *$ \\
\hline Tourism and promotion & 0.227 & $0.000 *$ & $\begin{array}{l}\text { Above average } \\
\text { Below average }\end{array}$ & $\begin{array}{l}3.267 \\
2.342\end{array}$ & 12.009 & 0.001 & 12090 & $0.000^{*}$ \\
\hline Youth programmes & 0.166 & $0.001 *$ & $\begin{array}{l}\text { Above average } \\
\text { Below average }\end{array}$ & $\begin{array}{l}3.033 \\
2.485\end{array}$ & 13.577 & 0.000 & 14018 & $0.016^{*}$ \\
\hline Old town revitalisation & 0.394 & $0.000 *$ & $\begin{array}{l}\text { Above average } \\
\text { Below average }\end{array}$ & $\begin{array}{l}3.659 \\
2.216\end{array}$ & 4.751 & 0.030 & 9706 & $0.000 *$ \\
\hline Underprivileged groups & 0.094 & 0.067 & $\begin{array}{l}\text { Above average } \\
\text { Below average }\end{array}$ & $\begin{array}{l}2.917 \\
2.446\end{array}$ & 13.876 & 0.000 & 12956 & $0.033 *$ \\
\hline $\begin{array}{l}\text { Commerce, development and } \\
\text { employment }\end{array}$ & 0.131 & $0.005^{*}$ & $\begin{array}{l}\text { Above average } \\
\text { Below average }\end{array}$ & $\begin{array}{l}2.854 \\
2.339\end{array}$ & 0.031 & 0.861 & 2.489 & $0.013 *$ \\
\hline Town-planning and housing & 0.094 & $0.035^{*}$ & $\begin{array}{l}\text { Above average } \\
\text { Below average }\end{array}$ & $\begin{array}{l}2.755 \\
2.288\end{array}$ & 6.908 & 0.009 & 12190 & $0.045 *$ \\
\hline Health & 0.133 & $0.005^{*}$ & $\begin{array}{l}\text { Above average } \\
\text { Below average }\end{array}$ & $\begin{array}{l}2.813 \\
2.102\end{array}$ & 4.726 & 0.030 & 12612 & $0.000 *$ \\
\hline Public safety & -0.019 & 0.359 & $\begin{array}{l}\text { Above average } \\
\text { Below average }\end{array}$ & $\begin{array}{l}1.720 \\
1.695\end{array}$ & 0.026 & 0.872 & 0.126 & 0.900 \\
\hline
\end{tabular}

Table 7: Town hall size and outsourcing

\begin{tabular}{|c|c|c|c|c|c|c|}
\hline & & & Levene & & & \\
\hline Size variables & Outsourcing Degree & Mean & $\mathrm{F}$ & Sign. & U Mann-Whitney & Sign. \\
\hline No. of inhabitants & $\begin{array}{l}\text { Above average } \\
\text { Below average }\end{array}$ & $\begin{array}{l}55,222 \\
28,077\end{array}$ & 34,771 & 0.000 & 15,564 & 0.005 \\
\hline Budget (€) & $\begin{array}{l}\text { Above average } \\
\text { Below average }\end{array}$ & $\begin{array}{l}147,640,000 \\
41,829,000\end{array}$ & 19,585 & 0.000 & 1,192 & 0.000 \\
\hline $\begin{array}{l}\text { Staff volume (No. } \\
\text { of workers) }\end{array}$ & $\begin{array}{l}\text { Above average } \\
\text { Below average }\end{array}$ & $\begin{array}{l}494 \\
263\end{array}$ & 26,257 & 0.000 & 13,630 & 0.015 \\
\hline
\end{tabular}


Table 8: Opinion about outsourcing

\begin{tabular}{|c|c|c|c|}
\hline Opinion about outsourcing & Mean & Median & Mode \\
\hline The outsourced services permit to offer a better service to citizens & 4.37 & 5 & 7 \\
\hline The town hall has a good control over the outsourced services & 4.04 & 4 & 6 \\
\hline The outsourced services make it possible to save costs & 3.96 & 4 & 6 \\
\hline The outsourced services allow us to keep a good image among citizens & 3.94 & 4 & 4 \\
\hline $\begin{array}{l}\text { Increasing the number of outsourced services would permit to improve the } \\
\text { services delivered to citizens }\end{array}$ & 3.70 & 4 & 4 \\
\hline The number of services subcontracted with external firms is very high & 3.44 & 4 & 3 \\
\hline
\end{tabular}

Table 9: Town hall strategic profile

\begin{tabular}{|c|c|c|c|}
\hline & Mean & Median & Mode \\
\hline We try to ensure that services reach the highest possible number of citizens & 5.763 & 6 & 7 \\
\hline We try to ensure that services reach social minorities & 5.213 & 5 & 6 \\
\hline Offering new services to the existing citizens is a priority & 4.736 & 5 & 5 \\
\hline The services that we offer are focused on traditional areas & 4.694 & 5 & 5 \\
\hline We try to use internal resources in the delivery of services & 4.685 & 5 & 5 \\
\hline $\begin{array}{l}\text { External pressures are the ones which exert the strongest influence on the } \\
\text { services offered }\end{array}$ & 4.638 & 5 & 5 \\
\hline Offering the existing services to new users is a priority & 4.589 & 5 & 4 \\
\hline Cost savings are essential when it comes to deliver a service & 4.473 & 4 & 4 \\
\hline $\begin{array}{l}\text { The services that we offer are in the vanguard of the most innovative town } \\
\text { halls }\end{array}$ & 3.869 & 4 & 4 \\
\hline We seek private sector involvement in the delivery of services & 3.745 & 4 & 3 \\
\hline A good short-term and long-term strategic planning exists & 3.366 & 3 & 5 \\
\hline
\end{tabular}


Table 12: Correlation analysis, equality of means test, prospective strategy and priority

\begin{tabular}{|c|c|c|c|c|c|c|c|c|}
\hline & & & & & Levene & & & \\
\hline Prospective strategy & $\begin{array}{c}\text { Pearson's } \\
\text { R }\end{array}$ & Sign. & $\begin{array}{c}\text { Priority given to } \\
\text { activity }\end{array}$ & Mean & $\mathrm{F}$ & Sign. & $\begin{array}{l}\text { T (student) or U } \\
\text { Mann-Whitney }\end{array}$ & Sign. \\
\hline Environmental quality & 0.597 & $0.000^{*}$ & $\begin{array}{l}\text { More important } \\
\text { Less important }\end{array}$ & $\begin{array}{l}0.434 \\
-0.615\end{array}$ & 0.929 & 0.336 & 11.154 & $0.000^{*}$ \\
\hline $\begin{array}{l}\text { Commerce, development and } \\
\text { employment }\end{array}$ & 0.547 & $0.000^{*}$ & $\begin{array}{l}\text { More important } \\
\text { Less important }\end{array}$ & $\begin{array}{l}0.300 \\
-0.744\end{array}$ & 1.976 & 0.161 & 9.862 & $0.000^{*}$ \\
\hline Culture & 0.506 & $0.000^{*}$ & $\begin{array}{l}\text { More important } \\
\text { Less important }\end{array}$ & $\begin{array}{l}0.192 \\
-0.735\end{array}$ & 2.253 & 0.134 & 7.393 & $0.000^{*}$ \\
\hline $\begin{array}{l}\text { Cleaning, parks and rubbish } \\
\text { collection }\end{array}$ & 0.532 & $0.000 *$ & $\begin{array}{l}\text { More important } \\
\text { Less important }\end{array}$ & $\begin{array}{l}0.399 \\
-0.571 \\
\end{array}$ & 0.353 & 0.553 & 9.950 & $0.000^{*}$ \\
\hline Facility maintenance & 0.521 & $0.000^{*}$ & $\begin{array}{l}\text { More important } \\
\text { Less important }\end{array}$ & $\begin{array}{l}0.463 \\
-0.570\end{array}$ & 0.079 & 0.779 & 11.069 & $0.000^{*}$ \\
\hline Tourism and promotion & 0.358 & $0.000^{*}$ & $\begin{array}{l}\text { More important } \\
\text { Less important }\end{array}$ & $\begin{array}{l}0.232 \\
-0.324\end{array}$ & 0.068 & 0.794 & 5.157 & $0.000^{*}$ \\
\hline Underprivileged groups & 0.539 & $0.000^{*}$ & $\begin{array}{l}\text { More important } \\
\text { Less important }\end{array}$ & $\begin{array}{l}0.296 \\
-0.674\end{array}$ & 0.283 & 0.595 & 9.187 & $0.000^{*}$ \\
\hline Youth & 0.465 & $0.000^{*}$ & $\begin{array}{l}\text { More important } \\
\text { Less important }\end{array}$ & $\begin{array}{l}0.302 \\
-0.525\end{array}$ & 0.411 & 0.522 & 8.023 & $0.000^{*}$ \\
\hline Sports & 0.437 & $0.000 *$ & $\begin{array}{l}\text { More important } \\
\text { Less important }\end{array}$ & $\begin{array}{l}0.191 \\
-0.539\end{array}$ & 0.216 & 0.642 & 6.186 & $0.000 *$ \\
\hline Seniors' programmes & 0.417 & $0.000^{*}$ & $\begin{array}{l}\text { More important } \\
\text { Less important }\end{array}$ & $\begin{array}{l}0.214 \\
-0.483\end{array}$ & 0.181 & 0.671 & 6.247 & $0.000^{*}$ \\
\hline Old town revitalisation & 0.328 & $0.000^{*}$ & $\begin{array}{l}\text { More important } \\
\text { Less important }\end{array}$ & $\begin{array}{l}0.280 \\
-0.253\end{array}$ & 0.262 & 0.609 & 4.974 & $0.000^{*}$ \\
\hline Health & 0.583 & $0.000 *$ & $\begin{array}{l}\text { More important } \\
\text { Less important }\end{array}$ & $\begin{array}{l}0.385 \\
-0.647\end{array}$ & 6.616 & 0.011 & 5804 & $0.000^{*}$ \\
\hline Public safety & 0.405 & $0.000^{*}$ & $\begin{array}{l}\text { More important } \\
\text { Less important }\end{array}$ & $\begin{array}{l}0.200 \\
-0.569\end{array}$ & 0.614 & 0.434 & 6.556 & $0.000 *$ \\
\hline Public transport & 0.530 & $0.000^{*}$ & $\begin{array}{l}\text { More important } \\
\text { Less important }\end{array}$ & $\begin{array}{l}0.326 \\
-0.576\end{array}$ & 0.455 & 0.500 & 8.283 & 0.000 \\
\hline Town-planning and housing & 0.371 & $0.000^{*}$ & $\begin{array}{l}\text { More important } \\
\text { Less important }\end{array}$ & $\begin{array}{l}0.192 \\
-0.411 \\
\end{array}$ & 0.057 & 0.811 & 5.297 & $0.000^{*}$ \\
\hline
\end{tabular}


Table 13: Correlations analysis, equality of means test, defensive strategy and priority

\begin{tabular}{|c|c|c|c|c|c|c|c|c|}
\hline & & & & & Levene & & & \\
\hline Defensive strategy & $\begin{array}{c}\text { Pearson's } \\
\text { R }\end{array}$ & Sign. & $\begin{array}{c}\text { Priority given to } \\
\text { activity }\end{array}$ & Mean & $\mathrm{F}$ & Sign. & $\begin{array}{l}\text { T (student) or U } \\
\text { Mann-Whitney }\end{array}$ & Sign. \\
\hline Environmental quality & 0.222 & $0.000 *$ & $\begin{array}{l}\text { More important } \\
\text { Less important }\end{array}$ & $\begin{array}{l}0.141 \\
-0.212\end{array}$ & 1.720 & 0.191 & 3.264 & $0.001 *$ \\
\hline $\begin{array}{l}\text { Commerce, development and } \\
\text { employment }\end{array}$ & 0.283 & $0.000^{*}$ & $\begin{array}{l}\text { More important } \\
\text { Less important }\end{array}$ & $\begin{array}{l}0.122 \\
-0.324 \\
\end{array}$ & 0.122 & 0.728 & 3.790 & $0.000 *$ \\
\hline Culture & 0.125 & $0.020^{*}$ & $\begin{array}{l}\text { More important } \\
\text { Less important }\end{array}$ & $\begin{array}{l}0.061 \\
-0.239\end{array}$ & 9.306 & 0.002 & 8084 & $0.035^{*}$ \\
\hline $\begin{array}{l}\text { Cleaning, parks and rubbish } \\
\text { collection }\end{array}$ & 0.357 & $0.000 *$ & $\begin{array}{l}\text { More important } \\
\text { Less important }\end{array}$ & $\begin{array}{l}0.192 \\
-0.300\end{array}$ & 0.077 & 0.781 & 4.638 & $0.000^{*}$ \\
\hline Facility maintenance & 0.296 & $0.000 *$ & $\begin{array}{l}\text { More important } \\
\text { Less important }\end{array}$ & $\begin{array}{l}0.118 \\
-0.184\end{array}$ & 4.860 & 0.028 & 12252 & $0.008 *$ \\
\hline Tourism and promotion & 0.128 & $0.018^{*}$ & $\begin{array}{l}\text { More important } \\
\text { Less important }\end{array}$ & $\begin{array}{l}0.112 \\
-0.167 \\
\end{array}$ & 2.116 & 0.147 & 2.513 & $0.012 *$ \\
\hline Underprivileged groups & 0.244 & 0.000 & $\begin{array}{l}\text { More important } \\
\text { Less important }\end{array}$ & $\begin{array}{l}0.128 \\
-0.311 \\
\end{array}$ & 1.181 & 0.278 & 3.796 & $0.000 *$ \\
\hline Youth & 0.321 & $0.000^{*}$ & $\begin{array}{l}\text { More important } \\
\text { Less important }\end{array}$ & $\begin{array}{l}0.152 \\
-0.303\end{array}$ & 0.733 & 0.392 & 4.172 & $0.000 *$ \\
\hline Sports & 0.186 & $0.001 *$ & $\begin{array}{l}\text { More important } \\
\text { Less important }\end{array}$ & $\begin{array}{l}0.090 \\
-0.276\end{array}$ & 1.001 & 0.318 & 2.971 & $0.003^{*}$ \\
\hline Seniors' programmes & 0.260 & $0.000^{*}$ & $\begin{array}{l}\text { More important } \\
\text { Less important }\end{array}$ & $\begin{array}{l}0.121 \\
-0.296 \\
\end{array}$ & 1.846 & 0.175 & 3.604 & $0.000 *$ \\
\hline Old town revitalisation & 0.026 & 0.643 & $\begin{array}{l}\text { More important } \\
\text { Less important }\end{array}$ & $\begin{array}{l}0.025 \\
-0.054 \\
\end{array}$ & 0.358 & 0.550 & 0.732 & 0.465 \\
\hline Health & 0.234 & $0.000^{*}$ & $\begin{array}{l}\text { More important } \\
\text { Less important }\end{array}$ & $\begin{array}{l}0.163 \\
-0.301 \\
\end{array}$ & 5.486 & 0.020 & 9984 & $0.000 *$ \\
\hline Public safety & 0.123 & $0.022 *$ & $\begin{array}{l}\text { More important } \\
\text { Less important }\end{array}$ & $\begin{array}{l}0.093 \\
-0.270\end{array}$ & 3.077 & 0.080 & 2.956 & $0.003 *$ \\
\hline Public transport & 0.038 & 0.504 & $\begin{array}{l}\text { More important } \\
\text { Less important }\end{array}$ & $\begin{array}{l}0.001 \\
-0.093\end{array}$ & 0.137 & 0.711 & 0.790 & 0.430 \\
\hline Town-planning and housing & 0.230 & $0.000 *$ & $\begin{array}{l}\text { More important } \\
\text { Less important }\end{array}$ & $\begin{array}{l}0.129 \\
-0.328 \\
\end{array}$ & 3.725 & 0.054 & 3.899 & $0.000 *$ \\
\hline
\end{tabular}


Table 14: Correlation analysis, equality of means test, reactive strategy and priority

\begin{tabular}{|c|c|c|c|c|c|c|c|c|}
\hline & & & & & Levene & & & \\
\hline Reactive strategy & $\begin{array}{c}\text { Pearson's } \\
\text { R }\end{array}$ & Sign. & $\begin{array}{c}\begin{array}{c}\text { Priority given to } \\
\text { activity }\end{array} \\
\end{array}$ & Mean & $\mathrm{F}$ & Sign. & $\begin{array}{l}\text { T (student) or U } \\
\text { Mann-Whitney }\end{array}$ & Sign. \\
\hline Environmental quality & -0.072 & 0.181 & $\begin{array}{l}\text { More important } \\
\text { Less important }\end{array}$ & $\begin{array}{l}0.024 \\
-0.048\end{array}$ & 2.490 & 0.115 & 0.659 & 0.511 \\
\hline $\begin{array}{l}\text { Commerce, development and } \\
\text { employment }\end{array}$ & -0.136 & $0.011^{*}$ & $\begin{array}{l}\text { More important } \\
\text { Less important }\end{array}$ & $\begin{array}{l}-0.048 \\
0.105\end{array}$ & 0.372 & 0.542 & -1.284 & $0.000^{*}$ \\
\hline Culture & -0.016 & 0.766 & $\begin{array}{l}\text { More important } \\
\text { Less important }\end{array}$ & $\begin{array}{l}0.006 \\
-0.076\end{array}$ & 0.713 & 0.399 & 0.613 & 0.540 \\
\hline $\begin{array}{l}\text { Cleaning, parks and rubbish } \\
\text { collection }\end{array}$ & 0.001 & 0.980 & $\begin{array}{l}\text { More important } \\
\text { Less important }\end{array}$ & $\begin{array}{l}0.012 \\
-0.076 \\
\end{array}$ & 4.167 & 0.042 & 0.818 & 0.414 \\
\hline Facility maintenance & -0.187 & $0.000^{*}$ & $\begin{array}{l}\text { More important } \\
\text { Less important }\end{array}$ & $\begin{array}{l}-0.074 \\
0.087\end{array}$ & 0.161 & 0.688 & -1.484 & 0.139 \\
\hline Tourism and promotion & -0.032 & 0.551 & $\begin{array}{l}\text { More important } \\
\text { Less important }\end{array}$ & $\begin{array}{l}-0.030 \\
0.044 \\
\end{array}$ & 0.377 & 0.540 & -0.673 & 0.501 \\
\hline Underprivileged groups & -0.029 & 0.585 & $\begin{array}{l}\text { More important } \\
\text { Less important }\end{array}$ & $\begin{array}{l}0.016 \\
-0.057\end{array}$ & 0.189 & 0.664 & 0.632 & 0.528 \\
\hline Youth & -0.110 & $0.041^{*}$ & $\begin{array}{l}\text { More important } \\
\text { Less important }\end{array}$ & $\begin{array}{l}-0.014 \\
-0.001\end{array}$ & 0.110 & 0.740 & -0.112 & 0.911 \\
\hline Sports & -0.081 & 0.132 & $\begin{array}{l}\text { More important } \\
\text { Less important }\end{array}$ & $\begin{array}{l}0.023 \\
-0.103 \\
\end{array}$ & 0.687 & 0.408 & 1.025 & 0.306 \\
\hline Seniors' programmes & -0.046 & 0.388 & $\begin{array}{l}\text { More important } \\
\text { Less important }\end{array}$ & $\begin{array}{l}-0.015 \\
0.018\end{array}$ & 0.554 & 0.457 & -0.290 & 0.772 \\
\hline Old town revitalisation & 0.001 & 0.990 & $\begin{array}{l}\text { More important } \\
\text { Less important }\end{array}$ & $\begin{array}{l}0.004 \\
-0.066\end{array}$ & 4.767 & 0.030 & 12880 & 0.413 \\
\hline Health & -0.095 & 0.077 & $\begin{array}{l}\text { More important } \\
\text { Less important }\end{array}$ & $\begin{array}{l}-0.035 \\
0.044\end{array}$ & 0.336 & 0.562 & -0.716 & 0.474 \\
\hline Public safety & 0.062 & 0.251 & $\begin{array}{l}\text { More important } \\
\text { Less important }\end{array}$ & $\begin{array}{l}0.053 \\
-0.197\end{array}$ & 1.406 & 0.237 & 2.026 & $0.043^{*}$ \\
\hline Public transport & -0.030 & 0.590 & $\begin{array}{l}\text { More important } \\
\text { Less important }\end{array}$ & $\begin{array}{l}0.069 \\
0.098 \\
\end{array}$ & 0.268 & 0.605 & -0.977 & 0.329 \\
\hline Town-planning and housing & 0.076 & 0.160 & $\begin{array}{l}\text { More important } \\
\text { Less important }\end{array}$ & $\begin{array}{l}0.025 \\
-0.097 \\
\end{array}$ & 3.529 & 0.061 & 1.028 & 0.305 \\
\hline
\end{tabular}

Figure 1: Interviewees' profile

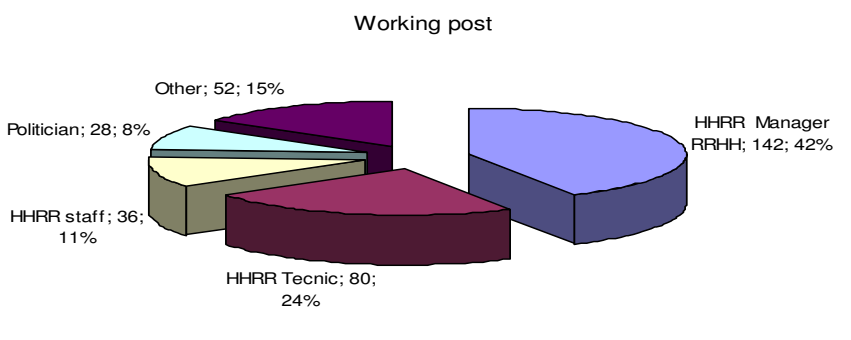

Sexo
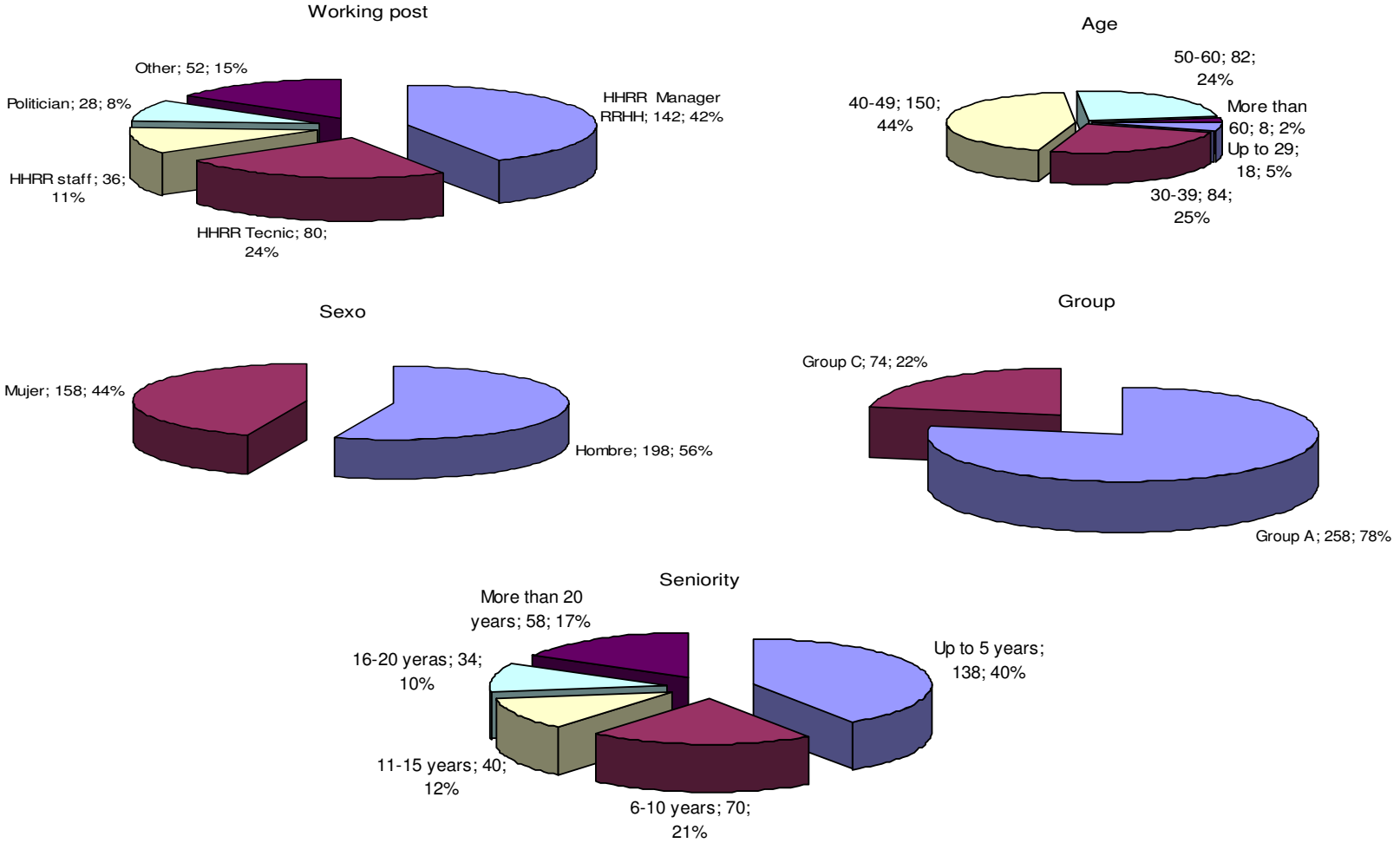
